\title{
GENERAL SURVEY ON CERTAIN HELMINTH PARASITES INFECTING SOME NILE FISHES AT EL-MINSOURA, EGYPT.
}

\author{
Mohamed F. A. Mansour'; Sameh H. Hassan ' ${ }^{1}$ Abd El-Aziz A. \\ Khidr $^{2}$ and Mosad A. Ghanem ${ }^{2}$. \\ 1 - Zoology dept.. Fac. of Science, Mansoura Univ.. Egypt. \\ 2- Zoology dept.. Fac. of Science (Damitta), Man soura Univ., \\ Egypt.
}

Key words: helminth parasites, trematodes, nematodes, River Nile, freshwater fishes.

\begin{abstract}
$\mathrm{T}$ he present investigation deals with certain helminth parasites which infect the freshwater fishes in the Nile River and its common tributaries at Dakahlyia Governorate near El-Mansoura city, Egypt.

The examined fishes were identified as Bagrus bajad: B.docmac; Synodontis schall; S. serratus; Mormyrus caschive: Barbus bynni; Lates niloticus and Labeo niloticus. These fishes were investigated monthly after weighing and measuring them and most of their internal organs were examined for helminth parasites.

The following trematodes were recorded: Acamthodtomum absconditum; Haplorchoides cahirinus; Phyllodistomum aegyptiacus;: metacercariae of Diplostomum sp ; of Neodiplostomum sp and of Posthodiplostonum sp. Moreover, two nematode species were reported, namely: Spinitectus moraveci and Capillaria yamagutii. Meanwhile, no cestode parasites were recorded in this study.

Out of 400 collected fishes, 349 were found to harbour one or more types of parasites. The general infection rate was $87.25 \%$. The infestation rate was highest in Bagrus baiad $(97.7 \%)$ followed by Bagrus docmac (93.33\%), while the lowest rate was recorded in Barbus bynni (69.7\%).

It was noticed that single infection was recorded for trematodes and nematodes in hostfishes. Double infection was not detected in Barbus bynni and was very rate in other fishes except $B$. bajad and $B$. docmac.

The relation between fish host parameters (body length. weight and sex) and each of the prevalence and intensity of infection were
\end{abstract}


studied in the present investigation. A significant correlation was found between the host length and infection prevalence, between the host weight and prevalence and between the host sex and intensity of infection, while insignificant relation was recorded between the host length or weight and intensity; and between host sex and prevalence of infection.

\section{INTRODUCTION}

In order to follow up the present status of parasitic helminthes infesting freshwater fishes in Egypt, it was important to deal with them as two groups:

1- Studies concerned with incidence- and seasonal dynamics.

2- Studies concerned with taxonomy and morphology of the parasites.

The first group was dealt by many authors such as; Imam (1971); El-Naffar and Saoud (1974); Moravec (1975); Fahmy et al.,(1976); Moravec (1977); Wannas (1977); Tadros et al.,(1978); Imam et al.,(1979); Noor El-Din (1981); Sahlab (1982); El-Naffar et al.,(1983); Abu El-Hag (1985); Negm El-Din (1987); El-Naggar and Khidr (1987); Khidr (1990) and Hagras et al.,(1995).

From the above review, it was clear that the incidence and seasonal dynamics of the parasitic fauna of the freshwater fishes in Dakahlyia Governorate attracted less attention of helminthologists. Therefore, this work was planned to study the parasites of certain freshwater fishes (other than Clarias spp. and Tilapia spp) through a complete year. The selected fishes also have high economic importance.

\section{MATERIALS AND METHODS}

Eight species of fishes belonging to four orders and five families had been collected from the Damietta branch of the River Nile and its tributaries at a distance about 20 kilometers around El-Mansoura City, Dakahlyia Governorate, Egypt. These fishes were identified using the references of Wheeler (1985); Holden-Day (1988) and Bishai \& Khalil 1997)

The host fishes were Bagrus bajad; Bagrus docmac; Mormyrus caschive; Labeo niloticus; Barbus bynni; Synodontis schall; Synodontis serratus and Lates niloticus. These fishes were brought alive to the laboratory, followed by taking brief notes on their identification; sex and date of collection. Each fish was weighed and 
measured from the anteriormost end of the head until the base of it. caudal fin (standard length).

The examined host fishes were divided into three length classes: class I (up to $15 \mathrm{~cm}$ ), class II (from 16- $20 \mathrm{~cm}$ ) and class III (over 21 $\mathrm{cm}$ ). Also, they were divided into three weight classes; class I (up to $20 \mathrm{gm}$ ), class II (from 21-160 gm) and class Ill (over $161 \mathrm{gm}$ ).

The host fishes were then dissected and their different internal organs were isolated in separate Petri-dishes containing saline solution $(0.6-0.9 \% \mathrm{NaCl})$. The organs examined were; the alimentary canal (oesophagus, stomach. intestine and rectum), ovaries, testes. kidneys, air sacs, muscles and the eyes. Each organ was opened by a fine scissor and left in the saline solution for some time with occasional shaking.

Using the dissecting microscope, the helminth parasites wer detached from the tissues. The collected worms were cleaned by washing several times in saline solution and counted.

Permanent preparations of the helminth parasites were done by using different fixatives such as formol saline and $70 \%$ ethyl alcoho: and different stains such as alum-carmine and aceto-carmine fo: trematodes, while the nematodes were prepared by lactophenol. trichrome stain method.

Statistical analysis were done to evaluate the results such as t-tes? and one way of variances (ANOVA test).

\section{RESULTS}

A total of 400 specimens from local freshwater fishes belonging to 8 species namely: Bagrus baicd; B. docmac; Synodontis schall; s' serratus; Mormyrus caschive; Barbus bynni; Labeo niloticus and Lates niloticus were examined for endoparasites. Results of this examination revealed that these host fishes were parasitized b: helminthes belonging to Digenea and Nematoda, while the cestodi parasites were not detected in the examined fish species. The digenetic trematodes which were found in this study were represente: by: Acanthostomum absconditum Looss, 1901; Haplorchoides cahirinus Looss, 1896; Phyllodistomum aegyptiacus n.sp: metacercariae of Diplostomum sp; Neodiplostomum sp. and o! Posthodiplostomum sp. Besides, two nematodes were identifie namely: Capillaria yamagutii Tadros and. Mahmoud, 1968 an' Spinitectus moraveci Boomker and Puylaert, 1994. 


\section{Micro-habitat of Parasites:}

As illustrated in Table (1), the digenetic trematodes were collected from the various examined organs of the fishes and distributed as follows: A. absconditum and Haplorchoides cahirinus from in the stomach and intestine of Bagrus bajad and B. docmac Phyllodistomum aegyptiacus from the testes and ovaries of $B$. bajad; $B$. docmac; Synodontis schall; Synodontis serratus and Lates niloticus. The metacercariae of both Diplastomum and Neodiplostomum from the eyeball of all the examined fishes, while the metacercariae sp of Posthodiplosiomum sp were collected from other organs than the eyes of Barbus bynni and Labeo niloticus.

Moreover, the nematode parasites were collected as follows: Capillaria yamaguiii from the intestine of Bagrus bajad. Mormyrus caschive and Lates niloticus. Finally, specimens of Spinitecrus moraveci were collected from the stomach of B. bajad; $B$. docmac; Synodontis schall; Synodontis serratus and Lates niloticus.

\section{General Prevalence:}

Table (2) and Figure (1) show that the general prevalence of infection was highest in $B$. bajad $(97.7 \%)$, while the lowest was recorded in Barbus bynni (69.7\%).

\section{Community structure:}

Table (3)and Figure (2) illustrate the percentages of infection of trematodes that were higher than those of nematodes in all examined fishes. The highest infection of trematodes was in Barbus bynni $(100 \%)$, while the lowest one was in Bagrus bajad (77.95). Moreover, the highest infection of nematodes was recorded in B.bajad (22.05). while no nematodes were detected in Barbus bynni $(0.0 \%)$.

\section{Combination of major groups of parasites (Table 4 and Fig.3)}

\section{A) Single infection:}

The single infection of trematodes was recorded in all exanined fishes with a minimum percentage (77.95) in B. bajad, and a maximum percentage $(100 \%)$ in Barbus bynni with the total percentage of $87.67 \%$. The nematodes single infection were found in all the examined fishes except Barbus bynni. Their minimum percentage was $2.94 \%$ in Synodontis schall, maximum percentage was $22.05 \%$ in B. bajad and a total percentage $12.32 \%$. It was noticed that the total percentage of single infection of nematodes was much lower than that of trematodes in all of the examined fishes except in genus Bagrus which had highest percentages $(22.05 \%$ in B. bajad and $21.42 \%$ in $B$. docmac). 


\section{B) Double infection :}

In the present study, double infection represented by nematodes and trematodes was very low in all the examined fishes except Bagrus bajad and $B$. docmac which had the highest values of double infections. The minimum and maximum percentages were $2.94 \% \mathrm{in}$ Synodontis schall and $27.6 \%$ in Bagrus bajad respectively. This double infection was not detected in Barbus bynni.

There was no triple infection, as the cestodes were not recorded in this investigation.

Relation between the host length and prevalence of infection:

As illustrated in Table (5) and Figure (4), there are minor differences in the prevalence of helminth infection in the different host length classes. Hosts of class II are somewhat more susceptible to infection followed by hosts of class III and then class I. The higher and lower prevalence of length class II were $40.0 \%$ in May and September and $28.57 \%$ in March respectively. The maximum and minimum prevalence for host length class III were $41.37 \%$ and $26.66 \%$ in January and in May respectively. Furthermore, the hosts of length class I presented the lowest prevalences in six months. The maximum and minimum prevalence for this class were $39.13 \%$ and $24.14 \%$ in April and in January respectively.

One way ANOVA test revealed that there are highly significant differences in prevalences of helminthes among the three. length classes of the examined hosts $(D F=35, F$-ratio $=106.82, F$-probability $<0.0001$ ).

Relation between the host length and intensity of infection:

Table (6) and Figure (5) revealed the effect of host length on the intensity of infection thrugh the period of study. The minimum and maximum intensity of host length class I were 2.59 in February and 5 in November respectively, while those of class II were 2.5 in July and 3.86 in April respectively. Moreover, the minimum and maximum intensity of class III were 2.38 in July and 6 in December respectively. It was concluded that the intensities of infection of the three classes are nearly similar along the period of study with minor differences.

One-way ANOVA test revealed insignificant differences in the intensities of infection among the three length classes of the examined fishes. 
Relation between the host weight and prevalence of infection:

The effect of host weigin on the prevalence of infection was illustrated in Table (7) and Figure (6). It was obviously noted that the prevalence of host weight class III, had the lowest values during the period of study with minimum and maximum values 10.34 in November and 21.8 in February respectively. The prevalence of host weight class 1 , was the highest in most of months of study with minimum and maximum values 36.6 in May and 55.17 in November respectively. Moreover, the minimum and maximum values of prevalence of class Il were 10.34 in November and 21.8 in February respectively.

One way ANOVA test revealed that there are highly significant differences in the prevalences of infection among the three weight classes of the examined hosts $(\mathrm{DF}=35, \mathrm{~F}$-ratio $=96.96, \mathrm{~F}$-probability $=$ 0.0001).

\section{Relation between the host weight and intensity of infection:}

Table (8) and Figure (7) show that the intensities of the host weight classes had low values. These values were nearly similar to each other allover the period of study except in four months (March, April, May and December) where the hosts of weight class III had the highest values. The minimum and maximum values of intensities of the three classes were; 2.67 in February and 5 in November for class I; 2.08 in May and 4.22 in August for class II and 2.25 in June and 6.5 in May for class 111 respectively.

One-way. ANOVA test revealed insignificant differences in the intensities of infection among the three weight classes of the examined host fishes.

\section{Relation between the host sex and prevalence of infection}

The effect of sex of the host fishes on the prevalence of infection was illustrated in Table (9) and Figure (8). It was clear that the prevalence in males was $100 \%$ in January, February, September and December, while it was $100 \%$ for females in October and December only. The minimum prevalences in males and females were 69.2 in April and $50 \%$ in March respectively. In most of the year, the prevalence of males was slightly higher than of females.

T-test statistical analysis reveals that there are non-significant differences between the prevalences of the infected males and females of the examined host fishes.

Relation between the host sex and intensity of infection 
The intensities of infection of male and female fishes are illustrated in Table (10) and Figure (9). The intensities in males were higher than in females allover the period of study, except in two months (March and September) where those in females were higher than in males. The minimum and maximum intensities were 3.67 in September and 6.13 in November for males and 2 in October and 6.33 in March for females respectively.

Statistically, t-test revealed significant differences between males and females of the infected fishes.

\section{DISCUSSION}

In the present study, three adult digenean species, two adult nematode ones, and three metacercariae of digeneans were collected. The digenean parasites were Acanthostomum absconditum Looss, 1901; Haplorchoides cahirimus Looss, 1896; Phyllodislomum aegyptiacus n. sp., Diplostomum sp; Neodiplostomum sp. and Posthodiplostomum sp. The nematode parasites were Spinitectus moraveci Boomker and Puylaert, 1994; Capillaria yamaguti Tadros and Mahmoud 1968.

During the period of study, two freshwater fishes Bagrus bajad and $B$. docmac were found to harbour all the above menituned parasite species except Posthodiplostomum sp. in B. bajad and Posthodiplost-omum sp. and Capillaria yamaguti in B. docmac. These host fishes had the highest prevalence $(97.69 \%$ in B. bajad and $93.33 \%$ in B. docmac). Such results agreed with Fahmy \& Selim (1959); Moravec (1977) and Shalaby et al.. (1987).

Analysis of the parasites in the present investigation (Tables $1 \& 11$ ) indicates that these species can be roughly divided into four groups according to the degree of their host specificity: Group I strictly specific species occurring only in two hosts (Posthodiplostomum sp., Acanthostomum absconditum and Haplorchoides cahirinus). Group II including species parasitizing three host species (Capillaria yamaguti). Group III the parasites infecting five host fish species (Neodiplostomum sp.; Phyllodistomum aegyptiacus and Spinitectus morciveci). Group IV those infect all the examined host fishes (Diplostomum sp.).

Comparison among the above groups revealed that the freshwater genus Bagrus was specific host for the parasites $A$. absconditum and $H$. cahirinus in Egypt in accordance with Imam et 
al., (1991) and Arafa el al., (2002). The two host species B. bynni and L. niloticus were specific hosts for Posthodiplostomum sp. Moreover, the metacercariae of Diplostomum sp. have a wide range of host specificity as they were recorded from all of the examined fishes in the present study. These metacercariae were also reported previously from other fishes such as Tilapia spp. and Clarias spp. These results indicate that metacercariae have low host specificity that are considered to offer successful life cycles to these metacercariae which have to pass through three hosts; two intermediate hosts (snail and fish) and a final host (fish-eating birds) during their life cycles. These results are in agreement with Kawai and Yamoto (1936); Ito et al., (1967); Soh et al., (1976) and Shalaby et al., (1987).

It was concluded that the Nile fishes act as second intermediate hosts of some trematodes since most of these fishes specially those in the Nile tributaries are living near the shore where the first intermediate hosts (snails), as well as fishes are living where the infection with cercariae is facilitated. Such findings may help in the control of such trematodes. These results support the study of Shalaby et al., (1987).

The present study revealed that some of the examined fishes harboured a little number of parasites than others, in agreement with Rekharani and Madhavi (1985) who stated that the disappearance of some parasite species in fishes has been directly related to fluctuating salinity conditions because the infecting stages of the parasites and their intermediate hosts are mostly stenohaline. Moreover, Kennedy et al., (1986) stated that the number of parasite species that a fish species harbours varies widely from one host to another and from locality to another.

Interaction between fishes, \& terrestrial birds and mammals influences the parasite fauna of fish as stated by Wisniewski (1958); Chubb (1963); Esch (1971); Esch el al. (1975) and Cone \& Anderson (1977). This interaction is reflected in the present investigation by the presence of large number of helminthes using the examined fishes as intermediate hosts in case of the diplostomatid metacercariae.

The increase in the prevalence of helminth parasites may be also related to the increased foraging activity by fish responding to better feeding conditions which may increase their exposure to cercariae of trematodes in the nearshore littoral zone of the Nile and its branches, where the snails (the intermediate hosts) primarily occur, in accordance with Albert \& Curtis (1991). 
The prevalence of helminth parasites in this study increases with the increase in length of fishes and there is a highly significant difference in the prevalence among the three classes of host fishes in accordance with Muzzall (1980), while there is an insignificant difference in the intensities of the length classes of fishes as observed by Muzzall (1982) and Muzzall et al., (1990). The increased prevalence with increasing in fish length may be due to the increase and growth of the interenal organs of the hosts leading to the increase in the surface areas of infection as suggested by El-Naggar \& Khid. (1986); Khidr (1990) and Hagras et al., (1995) or could be due to the exposure time of infection (Muzzall et al., 1990). The increase of fish number in the habitat may increase the infection and the number of parasites as recorded by Muzzall et al., (1990).

The highly significant differences in prevalence between weight classes of host fishes are contrary with Muzzall et al.. (1990) but agree them in the case of intensities of the different weight classes where there are non-significant differences.

Marcogliese et al., (2001) found positive relationships between abundance of Diplodistomum spp and fish length, mass, gonad mass, condition index and gonadosomatic index. In the present investigation, there is an insignificant difference in the prevalence between males and females, while there is significant difference in their intensities.

\section{REFERENCES}

Abu El-Hag, S. A. T. A. (1985). Studies on the helminth parasites of some fishes from Sharkiya governorate. M. Sc. Thesis. Fac. Sc., Zagazig Univ., Egypt.

Albert, E. and Curtis. M. A. (1991). Prevalence and abundance of helminth parasites in an intensively fished population of brook trout (Salvelinu fontinalis) at a small subarctic lake. Can. J. zool., 69(3): 691-697.

Arafa, S. Z. ; Reda, E. S. ; El-Naggar, M. M. (2002). Cholinergic components of the nervous system of the digenean parasites, Haplorchoides cahirinus and Acanthostomum absconditum from the catfish Bagrus bajad in Egypt. Acta parasitol., $47(7): 272-279$. 
Bishai, H. M. and Khalil, M. T. (1997). Freshwater fishes of Egypt. Publ. Nat. Biodiv. Unit., 9: 229 pp.

Boomker, J. and Puylaert, F. A. (1994). Eight new Afrotropical Spinitectus spp. (Nematoda: Cystidicolidae) from freshwater fishes with a key to the members of the genus in the Region. Ondest. J. Vet. Res., 61: 127-142.

Chubb, J. C. (1963). Seasonal occurrence and maturation of Triaenophorus nodulosus (Pallas, 1781) (Cestoda: Pseudophyllidea) in the pike Esox lucius L. of Llyn Tegid. Parasitol., 53: 419-433.

Cone, D. K. and Anderson, R. C. (1977). Parasites of pumpkinssed (Lepomis gibbosus L.) from Rayan Lake, Algonquin Park, Ontario. Ontario-Can. J. Zool., 55: 1410-1423.

El-Naffar, N. K. and Saoud, M. F. A. (1974). Rhabdochona aegypiacus n.sp. (Nematoda: Rhabdochonidae) from some fresh water fishes of the River Nile at Assiut, Egypt. Bull. Zool. Soc. Egypt., 26: 45-49.

El-Naffar, M. K. ; Saoud. M. E. and Hassan. I. N. (1983). A gerneral survey of the helminth Parasites of some fish from Lake Nasser at Asswan, A.R. Egypt. Assiut. Vet. Med J., 1/(21) : 141-146.

El-Naggar, M. M. and Khidr, A. A. (1986). Population dynamics of cichlidogyrid monogeneans from the gills of three Tilapia spp. from Damietta branch of the River Nile in Egypt. Proc. Zool. Soc. A.R. Egypt., 12:275-286.

Esch, G. W. (1971). Impact of ecological succession on the parasite fauna in centrarchids from oligotrophic and eutrophic ecosystems. Am. Mid. Nat., 86:160-168.

Esch, G. W. ; Gibbons, J. W. and Bourgue, J. E. (1975). An analysis of the relationship between stress and parasitism. Am. Mid. Nat., 93:339-353. 
Fahmy, M. A. M. and Selim. M. K. (1959). Studies on some trematode parasites of dogs in Egypt with special reference to the role played by fish in their transmission. Z. F. Parasitenkunde, 19(3): 13.

Fahmy, M. A. M. ; Mandour, A. M. and El-Naffar. M. K. (1976). On some cestodes of the freshwater fishes in Assiut Province. Egypt. Vet. Mled. J., 24(24) : 253- 262.

Hagras. A. E. M. : El-Naggar. M. M. : Mansour. M. F. A. and ElNaggar, A. M. (1995). Influence of age, length and sex of the catfish Clarias lazera on infestation with Six Monogenean parasites. Mans. Sci. Bull. (B-Biology). 22(2) :37-55.

Holden-Day, Okland (1988). Freshwater Biology.Inc., USA : 108 pp.

Imam, E.A.E. (1971). Morphological and biological studies of the enteric helminthes infesting some of the Egyptian Nile fishes particularly Polyonchobothrium clarias of the Karmotes Clarias lazera and Clarias anguillaris M.D.Vet. Thesis, Fac. Vet. Med., Cairo Univ., Egypt.

Imam, E. A. E. ; El-Askalany, M. A. and Rashad, S. M. (1991). Studies on helminth parasites of Synodontis shall and Bagrus bajad from Beni-suef water resources. Ass. Vet. Med. J., 24(48) : 137-152.

Imam, E. A. ; Hassan, A. A. ; El- Shabrawy, K. N. and Tawfik, M. A. (1979). On some parasites of Nile, fishes in Egypt. $J$. of Egypt. Vet. Med. Assoc., I: 119-126.

Ito, J. ; Mochizuki, H. and Noguchi, M. (1967). An epidemiological study of human helminths in rural areas of Shizuok Prefecture. V. The prevalence of metacercariae of Metagonimus yokogawai in Plecoglosiss altivelis. Jap. J. Parasitol., 16(6): 441-446. 
Kawai, T. and Yamoto, Y. (1936). The distribution of the encysted cercariae of Clonorchis sinensis in the second intermediate host, Pseudorashora prava and the rate of their infections to the mammalian hosts. Taiwan Igakhai Zasshi., 35(4): 880887.

Kennedy, C. R. ; Laffoley, D. DA. ; Bishop, G. ; Jones, P. and Taylor, M. (1986). Communities of parasites of freshwater fish of Jersey, Channel Islands. J. Fish Biol. 29(2):215- 226.

Khidr, A. A. (1990). Population dynamics of Enterogyrus cichlidarum (Monogenea: Ancyrocephalinae) from the stomach of Tilapia spp. in Egypt. Int. J. Parasitol., 20(6): 741-745.

Looss, A. (1896). Recherche sur la fauna parasitaire de la Egypte. Premiére partie. Mém. Inst. Egypte, 3:1-252.

Looss, A. (1901). Uber die Fasciolidengenera Stephanochasmus, Acanthochasmus und einige andere. Centr. Bakt. Parsit. Infekt Abt., I(29): 592-606.

Marcogliese, D. J. ; Dumont, P. ; Gendron, A. D. ; Mailhot, Y. ; Bergeron, E. and Mclaughlin, D. (2001). Spatial and temporal variation in abundance of Diplostomum spp in walleye (Stizostedion vitream) and white suckers (Catostomus commersoni) from the St Lawrence River. Can. J. Zool. 79:355-369.

Moravec, F. (1975). The development of Procamallanus laeviconchus (Wedl, 1862) (Nematoda: Camallanus). Vest. Cs. Spot. Zool.. 39(1), 23-38.

Moravec, F. (1977). Some digenetic trematodes from Egyptian freshwater fishes. Vest. Cs. Spot. Zool., 41: 52-67.

Muzzall, P. M. (1980). Ecology and seasonal abundance of three acanthocephalan species inflesting white suckers in SE New Hampshire. J. Parasitol., 66: 127-133. 
Muzzall, P. M. (1982). Comparison of the parasite communities of the white sucker (Catostomus commersoni) from two rivers in New Hampshire. J. Parasitol., 68(2): 300-305.

Muzzall, P. M. ; Sweet, R. D. and Milewski, C. L. (1990). Occurrence of Diplostomum sp. (Trematoda: Diplostomatidae) in pond-reared walleyes from Michigan. Prog. Fish-Cult., 52(1): 53-56.

Negm-El Din, K. M. (1987). Some morphological studies on the internal parasites of fish Delta Nile. M.V. Sc. Thesis, Fac. Vet. Med., Zagzig Univ., Benha branch (Moshtohor), Egypt.

Noor El-Din, S. A. (1981). Studies on some parasitic helminthes in some freshwater fish. M. Sc. Thesis, Fac.Sci., Tanta Univ., Egypl.

Rekharani, Z. and Madhavi, R. (1985). Digenetic trematodes from mullets of Visakhapatnam (India). J. Nat. Hist., 19:929-951.

Sahlab, A. A. (1982). Studies on the enteric helminth parasites of fishes from Lake Manzala. M. Vet. Thesis, Fac.Vet. Med., Carro Univ., Egypt.

Shalaby, S. I. ; Selim, M. K. and Tawfik, M. A. A. (1987). Some studies on encysted metacercariae in some Nile fishes. Egypt. J. Vet. Sci., 2f(1): 63-71.

Soh, C. T. ; Lee, K.T. : Sho, K. M. ; Almm. Y. K. ; Kim, S. I. ; Chung. P. R. ; Im, K. I, ; Min, D. Y. ; Lee, I. H. and Chang, J. K. (1976). Prevalences of clonorchiasis and metagonimiasis along rivers in Jeonra-Nam-Do-Korea, Yonsei. Repo. Trop. Med., 7(1): 3-16.

Tadros, G. and Malmoud, M. I. (1968). On Capillaria yamagutii sp. nov (Nematoda: Trichuridae) from Nile fish Bagrus bajad. J.Vet. Sci., Unit. Arab. Repub., 5:133-142. 
Tadros, G. ; Iskandar. A. R. and Wassef, N. A. (1978). On some intestinal trematode from the Nile and Red Sea fishes with a histopathological changes of their habitat. J. Egypt. Soc. Parasitol. . 8(2) 383-392.

Wannas, M. K. A. (1977). Studies on certain helminth parasites of freshwater fishes from Lake Nasser. M. Sci.. Thesis, AlAzhar Univ.. Egypt.

Wheeler, A. (1985). The word Encyclopedia of fishes. A Macdonald book. This edition first published in Great Britain in 1985 by Macdonald \& Co. (Publishers) Ltd, London \& Sydney: $364 \mathrm{pp}$.

Wisniewski, W. L. (1958). Characterization of the parasite fauna of an eutropic lake (parasite fauna of the biocoenosis of Druzno lake, Part 1). Acta parasitol. Pol.. 6:1-64. 
Table (1): Microhgbitat distribution of the helminth parasites in the examined freshwster fishes.

\begin{tabular}{|c|c|c|}
\hline Examined Hosts fishes & Examined parasites & Intected orgens \\
\hline \multirow[t]{3}{*}{ (A) family: Bagridae } & Diplosiomum & Eye \\
\hline & Neodiplostomum & Eyc \\
\hline & Acanthostumum & stomach + intestine \\
\hline \multirow[t]{4}{*}{ Bagrus bayad } & Haplorchoides & $s t+i n t e$ \\
\hline & Phwllodistomum. & T'estis + ovary \\
\hline & Cappillaria & Intestine. \\
\hline & Spinitecius & stomach \\
\hline \multirow[t]{6}{*}{ Bagrus docmac } & Neodiplostomum. & Eyc \\
\hline & Diplosfomum & Eve \\
\hline & Acanthostumum & stomach + intestine \\
\hline & Hopjorchoides & stomach + islestine \\
\hline & Phyllodisiomum & Testis + ovary \\
\hline & Spinitectus & stomach \\
\hline \multirow{3}{*}{$\begin{array}{l}\text { (B) Family: Syonod midac } \\
\text { Synadonis schall }\end{array}$} & Diplostomum & Fye \\
\hline & Phyllodisiomum. & Ovary + Testis \\
\hline & Spinirecrus & Stomach \\
\hline \multirow[t]{3}{*}{ Si serralus } & Diplosiomum & Eye \\
\hline & Phyllodistomum. & Ovary + Testis \\
\hline & Spinirectus & stomach \\
\hline \multirow{2}{*}{$\begin{array}{l}\text { (C) Family: Mormyridae } \\
\text { Mormmrus caschive }\end{array}$} & Diplostomum & Eye \\
\hline & Capiliaria & Inlestine. \\
\hline \multirow{3}{*}{$\begin{array}{l}\text { (D) Family: Cyperinidac } \\
\text { Barbus bynni }\end{array}$} & Neodiplosicmum. & Iye \\
\hline & Diplostomum & Eye \\
\hline & Posorhodiplosionium & All orpans \\
\hline \multirow{3}{*}{ Labeo niloticus } & Neodiplosiomum & Eyc \\
\hline & Diplostomum & J:ye \\
\hline & Posothodiplostomum & $\begin{array}{c}\text { 1.iver + Kidney }{ }^{+} \\
\text {Muscles }\end{array}$ \\
\hline \multirow[t]{5}{*}{ (E) Family: Centropomidae } & Diplostomum & Eyc \\
\hline & Neodiplostomum & Eye \\
\hline & Phyllodistomum & Ovary + Testis \\
\hline & Capillaria & Intestinc. \\
\hline & Spinilectus & Stomach \\
\hline
\end{tabular}

Table (2): General prevalence of infeclion in the examined hostes.

\begin{tabular}{|l|c|c|c|}
\hline \multirow{2}{*}{ Examined host fishes } & Number Examined & Postitive & \\
\cline { 2 - 4 } & & number & $\%$ \\
\hline Bapus bayed & 130 & 127 & 97.69 \\
\hline B. docmac & 15 & 14 & 93.33 \\
\hline Synodontis schall & 82 & 68 & 82.93 \\
\hline S. serralus & 30 & 26 & 86.67 \\
\hline Mormyrus caschive & 20 & 15 & 75 \\
\hline Barbus byrni & 33 & 23 & 69.7 \\
\hline Labeo niloticus & 47 & 39 & 82.98 \\
\hline L.atcs niloticus & 43 & 37 & 86.05 \\
\hline Total & 400 & 349 & 87.25 \\
\hline
\end{tabular}


Table (3): The community structure of the helminth parasites infected the examined freshwater fishes:

\begin{tabular}{|c|c|c|c|c|c|c|c|c|c|}
\hline \multirow{3}{*}{$\begin{array}{l}\text { Examined host } \\
\text { fishes }\end{array}$} & \multirow{3}{*}{$\begin{array}{l}\text { Number } \\
\text { Examined }\end{array}$} & \multirow{3}{*}{$\begin{array}{c}\text { positive } \\
\text { No. }\end{array}$} & \multirow{3}{*}{$\%$} & \multicolumn{6}{|c|}{ Infections } \\
\hline & & & & \multicolumn{2}{|c|}{ Trematodes } & \multicolumn{2}{|c|}{ Nematodes } & \multicolumn{2}{|c|}{ Cestodes } \\
\hline & & & & No. & $\%$ & No. & $\%$ & No. & $\%$ \\
\hline Bagus bayed & 130 & 127 & 97.69 & 99 & 77.95 & 28 & 22.05 & 0 & 0 \\
\hline B. docmac & 15 & 14 & 93.33 & 11 & 78.57 & 3 & $21+3$ & 0 & 0 \\
\hline Synodontis schall & 82 & 68 & 82.93 & 66 & 9706 & 2 & 294 & 0 & 0 \\
\hline S. scrratus & 30 & 26 & 86.67 & 25 & 96.15 & 1 & 3.85 & 0 & 0 \\
\hline Mormyrus caschive & 20 & 15 & 75 & 12 & 80 & 3 & 20 & 0 & 0 \\
\hline Barbus bynni & 33 & 23 & 69.7 & 23 & 100 & 0 & 0 & 0 & () \\
\hline Labco niloticus & 47 & 39 & 82.98 & 35 & 89.74 & 4 & 10. 26 & () & 0 \\
\hline L.ates niloticus & 43 & 37 & 86.05 & 35 & 94.59 & 2 & 5.41 & 0 & 0 \\
\hline Total & 400 & 349 & 87.25 & 306 & 8768 & 43 & 1232 & () & () \\
\hline
\end{tabular}

Table (4): Single and simultaneous double and triple infection in the studied freshwater fishes:

\begin{tabular}{|c|c|c|c|c|c|c|c|c|c|c|c|c|c|c|c|}
\hline \multirow{4}{*}{$\begin{array}{l}\text { Eramined host } \\
\text { fistes }\end{array}$} & \multirow{4}{*}{$\begin{array}{l}\text { Number of } \\
\text { infected } \\
\text { fishes }\end{array}$} & \multicolumn{14}{|c|}{ Infections } \\
\hline & & \multicolumn{6}{|c|}{ Single } & \multicolumn{6}{|c|}{ double } & \multirow{2}{*}{\multicolumn{2}{|c|}{$\begin{array}{l}\text { (riple } \\
\text { Tri.t } \\
\text { Nemn+ } \\
\text { Ces. }\end{array}$}} \\
\hline & & \multicolumn{2}{|c|}{ Trematode } & \multicolumn{2}{|c|}{ Vematode } & \multicolumn{2}{|c|}{ Cestode } & \multicolumn{2}{|c|}{$\begin{array}{l}\text { Tre. } \\
\text { Nema. }\end{array}$} & \multicolumn{2}{|c|}{$\begin{array}{c}\text { Tremat } \\
\text { (ces. }\end{array}$} & \multicolumn{2}{|c|}{$\begin{array}{c}\text { Nemat } \\
\text { Ces. }\end{array}$} & & \\
\hline & & No & $\%$ & No & $\%$ & No. & $\%$ & No & ${ }_{0}^{\circ}$ & No & ${ }_{0}$ & No, & ${ }^{\circ} 0$ & No & $0_{0}$ \\
\hline Bagrus bayad & 127 & 99 & 77.95 & 28 & 2205 & 0 & 0 & 35 & 2756 & () & 0) & 0 & 0 & 0 & 0 \\
\hline B docmac & 14 & 11 & 78.57 & 3 & 21.43 & 0 & 0 & 3 & $21+3$ & 0 & 0 & 0 & 0 & 0 & 0) \\
\hline $\begin{array}{l}\text { Synodontıs } \\
\text { schall }\end{array}$ & 68 & 66 & 9706 & 2 & 2.94 & 0 & 0 & 2 & 294 & 0 & 0 & 0 & 0 & 0 & 0 \\
\hline S. serratus & 26 & 25 & 9615 & 1 & 3.85 & 0 & 0 & 1 & 3.85 & 0 & 0) & () & 0 & () & 0 \\
\hline $\begin{array}{l}\text { Mormyrus } \\
\text { caschive }\end{array}$ & 15 & 12 & 80 & 3 & 20 & 0 & 0 & 1 & 667 & 0 & 0 & 0 & 0 & 0 & 0 \\
\hline $\begin{array}{l}\text { Barbus bynni } \\
\text { Labeo } \\
\text { niloticus }\end{array}$ & 23 & $\begin{array}{l}23 \\
35 \\
\end{array}$ & $\begin{array}{r}100 \\
98.7 .4 \\
\end{array}$ & 0 & 1026 & $\begin{array}{l}0 \\
0 \\
\end{array}$ & 0 & 0 & $\begin{array}{r}0 \\
1026 \\
\end{array}$ & 0 & 0 & 0 & 0 & 0 & 0 \\
\hline Lates niloticus & 37 & 35 & 945 & 2 & 541 & 0 & 0 & 2 & 5.41 & 0 & 0 & 0 & 0 & 0 & 0 \\
\hline Total & 349 & 306 & 87.68 & 43 & 12.32 & 0 & 0 & 48 & 138 & 0 & 0 & 0 & 0 & 0 & 0 \\
\hline
\end{tabular}

Table (5): Relattion between the hosts length and the prevalence of infection

\begin{tabular}{|c|c|c|c|c|c|c|c|c|c|}
\hline \multirow{3}{*}{ Months } & \multirow{3}{*}{$\begin{array}{l}\text { Total } \\
\text { Exam }\end{array}$} & \multirow{3}{*}{$\begin{array}{l}\text { Total } \\
\text { infect }\end{array}$} & \multirow{3}{*}{$\%$} & \multicolumn{6}{|c|}{ Length classes } \\
\hline & & & & \multicolumn{2}{|c|}{ Class I } & \multicolumn{2}{|c|}{ Class II } & \multicolumn{2}{|c|}{ Class III } \\
\hline & & & & No & $\%$ & No & $\%$ & No & $\%$ \\
\hline Jan & 30 & 29 & 966 & 7 & 2414 & 10 & 34.48 & 12 & 41.37 \\
\hline Feb & 33 & 32 & 97 & 9 & 28.12 & 11 & 3437 & 12 & 375 \\
\hline March & 26 & 21 & 807 & 8 & 3809 & 6 & 2857 & 7 & 333 \\
\hline $\mathrm{Apr}$ & 33 & 23 & 69.7 & 9 & 39.13 & 7 & 30.44 & 7 & 3043 \\
\hline May & 40 & 30 & 75 & 10 & 3333 & 12 & 40) & 8 & 26.66 \\
\hline Jun & 33 & 29 & 87.8 & 9 & 3113 & 11 & 37.93 & 9 & 31.03 \\
\hline Jul & 35 & 29 & 82.8 & 9 & $3 ! 63$ & 11 & 37.93 & 9 & 31.03 \\
\hline Aug & 36 & 28 & 77.7 & 8 & 28.57 & 10 & 35.72 & 10 & 35.7 \\
\hline Sept & 32 & 30 & 93.7 & 9 & 30 & 12 & 40 & 9 & 30 \\
\hline $\mathrm{Oct}$ & 38 & 36 & 0.7 & 12 & 33.3 & 14 & 38.89 & 10 & 277 \\
\hline Nov & 31 & 29 & 93.5 & 9 & 31.03 & 11 & 37.93 & 9 & 31.03 \\
\hline Dec & 33 & 33 & 100 & 11 & 33.33 & 13 & 3939 & 9 & 28.125 \\
\hline
\end{tabular}

Class I ( up to $12 \mathrm{~cm}$ )

Class II $(13-20 \mathrm{~cm})$

Class III (over $21 \mathrm{~cm}$ ) 
- Sabie 6): Relation between the host length and the intensity of infection

\begin{tabular}{|c|c|c|c|c|c|c|c|c|c|c|c|}
\hline \multirow{3}{*}{ Months } & \multirow{3}{*}{ Tolal Exam } & \multirow{3}{*}{$\begin{array}{l}\text { Total } \\
\text { infect }\end{array}$} & \multicolumn{9}{|c|}{ Length elasses } \\
\hline & & & \multicolumn{3}{|c|}{ Class I } & \multicolumn{3}{|c|}{ Class II } & \multicolumn{3}{|c|}{ Class III } \\
\hline & & & $\begin{array}{c}\ln \mathbf{f} \\
\text { Host } \\
\end{array}$ & $\begin{array}{l}\text { no. of } \\
\text { worm }\end{array}$ & intensily & $\begin{array}{c}\text { inf } \\
\text { Host }\end{array}$ & no. of worm & intensity & $\begin{array}{l}\text { inf } \\
\text { Host }\end{array}$ & $\begin{array}{l}\text { mo. of } \\
\text { Horm }\end{array}$ & intensity' \\
\hline Jan & 30 & 29 & 10 & 35 & 3.5 & 12 & 40 & 3.3 .3 & 7 & 18 & 2.57 \\
\hline Feb. & 33 & 32 & 17 & 44 & 259 & 10 & 33 & 33 & 5 & 14 & 2.8 \\
\hline March $+A 64$ & 26 & 21 & 9 & 38 & 4.22 & 9 & 25 & 2.89 & 3 & 10 & 3.3 \\
\hline April & 33 & 23 & 10 & 30 & 3 & 8 & 31 & 3.86 & 5 & 17 & 34 \\
\hline May & 40 & 30 & 14 & 37 & 2.6 & 11 & 30 & 2.7 .3 & 5 & 28 & 56 \\
\hline Jun & 33 & 29 & 11 & 30 & 2.7 .3 & 11 & 36 & 3.27 & 7 & 27 & 3.86 \\
\hline July & 35 & 29 & II & 33 & 3 & 10 & 25 & 2.5 & 8 & 19 & 2.58 \\
\hline Agust & 36 & 28 & 14 & 40 & 2.86 & 9 & 30 & 3.3 & 5 & 17 & 34 \\
\hline Sept. & .32 & 30 & 12 & 41 & 3.42 & 12 & 40 & 3.3 & 6 & 30 & 5 \\
\hline Octab. & 38 & 36 & 15 & 52 & 3.47 & 15 & 45 & 3 & 6 & 24 & 483 \\
\hline Novemb. & 31 & 29 & 10 & 50 & 5 & 11 & 42 & 3.82 & 8 & 40 & 5 \\
\hline Decem. & 33 & 33 & 15 & 56 & 3.73 & 1.3 & 40 & 3.08 & 5 & 30 & b \\
\hline
\end{tabular}

Table (7): Relation between the host weight and prevalence

\begin{tabular}{|c|c|c|c|c|c|c|c|c|c|}
\hline \multirow{3}{*}{ Months } & \multirow{3}{*}{$\begin{array}{l}\text { Total } \\
\text { Exam }\end{array}$} & \multirow{3}{*}{$\begin{array}{l}\text { Total } \\
\text { infect. }\end{array}$} & \multirow{3}{*}{$\%$} & \multicolumn{6}{|c|}{ weight clusses } \\
\hline & & & & \multicolumn{2}{|c|}{ Class I } & \multicolumn{2}{|c|}{ Class II } & \multicolumn{2}{|c|}{ C.Iass 111 } \\
\hline & & & & No & $\%$ & $N_{0}$ & $\%$ & No & $\%$ \\
\hline $\operatorname{Jan}$ & 30 & 29 & 95.6 & 15 & 51.7 & 10 & 32.25 & 4 & 13.8 \\
\hline Feb & 33 & 32 & 97 & 15 & 46.8 & 10 & 31.25 & 7 & 21.8 \\
\hline March & 26 & 21 & 80.7 & 10 & 47.6 & 8 & 38.09 & 3 & 14.28 \\
\hline Apr & 33 & 23 & 69.7 & 10 & 45.45 & 9 & 40.9 & 4 & 17.4 \\
\hline May & 40 & 30 & 75 & 11 & 36.6 & 15 & 50 & 4 & 13.33 \\
\hline un & 33 & 29 & 87.8 & 10 & 34.48 & 14 & 48.27 & 5 & 17.24 \\
\hline Jul & 35 & 24 & 82.8 & 10 & 41.6 & 10 & 41.6 & 4 & 16.66 \\
\hline Aug & 36 & 28 & 77.7 & 11 & 39,28 & 13 & 46.42 & 4 & 14.28 \\
\hline Sept & .32 & 30 & 93.7 & 15 & 50 & 10 & 33.33 & 5 & 16.66 \\
\hline Oct & 38 & 36 & 94.7 & 16 & 44.44 & 14 & 38.88 & 6 & 16.60 \\
\hline Nov & 31 & 29 & 93.5 & 16 & 55.17 & 10 & 34.48 & 3 & 10.34 \\
\hline Dec & 33 & 33 & 100 & 17 & 53.13 & 11 & 34.37 & 5 & 15.15 \\
\hline
\end{tabular}

Class I ( up to $90 \mathrm{gm}$.)

Class II (9] - 160gm).

Class III (over $161 \mathrm{gm}$ ).

Table (8): Relation between the host weight and the inensity of infection

\begin{tabular}{|c|c|c|c|c|c|c|c|c|c|c|c|}
\hline \multirow{3}{*}{ Months } & \multirow{3}{*}{$\begin{array}{l}\text { Tola! } \\
\text { Exam }\end{array}$} & \multirow{3}{*}{$\begin{array}{l}\text { Total } \\
\text { infecl }\end{array}$} & \multicolumn{9}{|c|}{ Weutht classes } \\
\hline & & & \multicolumn{3}{|c|}{ Class 1} & \multicolumn{3}{|c|}{ Class II } & \multicolumn{3}{|c|}{ Class 1:! } \\
\hline & & & inf Host & tho af wort & Intensity & inf Host & no of warm & intensily & Inf Host & no of worm & inforatiy \\
\hline Jan & 30 & 29 & 12 & 45 & 3.75 & 12 & 38 & 3.17 & 5 & 21 & 4.2 \\
\hline Feb & 33 & 32 & 15 & 40 & 2.67 & 14 & 30 & 2.14 & 3 & 9 & 3 \\
\hline March & 26 & 21 & 10 & 37 & 3.7 & 9 & 27 & 3 & 2 & 10 & 5 \\
\hline April & 33 & 23 & 11 & 38 & 3.45 & 9 & 25 & 278 & 3 & 17 & 567 \\
\hline May & 40 & 30 & 16 & 51 & 3.19 & 12 & 25 & 208 & 2 & 13 & 65 \\
\hline Jum & 33 & 29 & 11 & 39 & 3.55 & 10 & 29 & 2.9 & 8 & 18 & 2.25 \\
\hline July & 35 & 29 & 12 & 40 & 3.33 & 10 & 32 & 3.2 & 7 & 20 & 286 \\
\hline Agus: & 36 & 28 & 12 & 43 & 3.58 & 9 & 38 & 4.22 & 7 & 24 & 3.43 \\
\hline Sept & 32 & 30 & 14 & 51 & 3.64 & 11 & 30 & 2.73 & 5 & $2 !$ & 42 \\
\hline Ocloh & 38 & 36 & 16 & 56 & 3.5 & 14 & 41 & 293 & 6 & 31 & 5.17 \\
\hline Novernb & 31 & 29 & 10 & 50 & 5 & 10 & 39 & 3.9 & 9 & 30 & 3.33 \\
\hline Decem & 33 & 33 & 15 & 54 & 3.6 & 13 & 40 & 3.08 & 5 & $3 i$ & 62 \\
\hline
\end{tabular}


Table (9): Relation between the host sex and prevalence of infection

\begin{tabular}{|l|c|c|c|c|c|c|}
\hline \multirow{2}{*}{ Month } & \multicolumn{3}{|c|}{ Males } & \multicolumn{3}{c|}{ Females } \\
\cline { 2 - 7 } & No. Eex & No. Infect & $\%$ & No. Ext & No. infect & $\%$ \\
\hline Jan & 22 & 22 & 100 & 8 & 7 & 87.5 \\
\hline Feb & 25 & 25 & 100 & 8 & 7 & 87.5 \\
\hline Mars & 20 & 18 & 90 & 6 & 3 & 50 \\
\hline Agril & 26 & 18 & 69.2 & 7 & 5 & 71.4 \\
\hline May & 32 & 25 & 78.13 & 8 & 5 & 62.5 \\
\hline Jun & 26 & 23 & 88.5 & 7 & 6 & 85.7 \\
\hline Jul & 26 & 22 & 84.6 & 9 & 7 & 77.8 \\
\hline Auggit & 26 & 19 & 73.07 & 10 & 9 & 90 \\
\hline Sept & 27 & 27 & 100 & 5 & 3 & 60 \\
\hline Oct & 28 & 26 & 92.85 & 10 & 10 & 100 \\
\hline Now & 24 & 23 & 95.8 & 7 & 6 & 85.7 \\
\hline Dec & 28 & 28 & 100 & 5 & 5 & 100 \\
\hline
\end{tabular}

Table (10): Relation between the host sex and the intensity of infection

\begin{tabular}{|c|c|c|c|c|c|c|c|c|}
\hline \multirow{2}{*}{ Wlonths } & \multirow{2}{*}{$\begin{array}{l}\text { Tolal } \\
\text { Exun }\end{array}$} & \multirow{2}{*}{ Total infec } & \multicolumn{3}{|c|}{ Males } & \multicolumn{3}{|c|}{ Fernales } \\
\hline & & & Inf. Hoss & no. of worm & intensity & inc. Host & no. of worm & intensity \\
\hline Jall & 30 & 29 & 24 & 144 & 6 & 5 & 30 & 6 \\
\hline lab. & 33 & 32 & 25 & 130 & 5.2 & 7 & 23 & 3.29 \\
\hline Mars. & 26 & 21 & 18 & 90 & 5 & 3 & 19 & 6.33 \\
\hline Aprit & 33 & 23 & 18 & 100 & 5.56 & 5 & 23 & 4.6 \\
\hline Mas & 40 & 30 & 25 & 112 & 4.48 & 5 & 15 & 3 \\
\hline StIII & 33 & 29 & 23 & 109 & 4.74 & 6 & 13 & 2.17 \\
\hline fuly & 35 & 29 & 22 & 152 & 6.91 & 7 & 21 & 3 \\
\hline A sust & 36 & 28 & 19 & 101 & 5.32 & 9 & 30 & 3.33 \\
\hline Sept. & 32 & 30 & 27 & 99 & 3.67 & 3 & 13 & 4.33 \\
\hline Octob. & 38 & 36 & 26 & 111 & 4.27 & 10 & 20 & 2 \\
\hline Novemb. & 31 & 29 & 23 & 141 & 6.13 & 6 & 30 & 5 \\
\hline Decerti. & 33 & 33 & 27 & 152 & 5.63 & 6 & 35 & 5.93 \\
\hline
\end{tabular}

\begin{tabular}{|c|c|c|c|c|c|c|c|c|}
\hline $\begin{array}{l}\text { Rerasite } \\
\text { Host }\end{array}$ & $\begin{array}{l}\text { A.absco- } \\
\text { nditum }\end{array}$ & $\begin{array}{l}\text { H.cahir- } \\
\text { inus }\end{array}$ & $\begin{array}{l}\text { P.aegypti- } \\
\text { acus }\end{array}$ & $\begin{array}{l}\text { Diplosto- } \\
\text { mum }\end{array}$ & $\begin{array}{l}\text { Neodiplo- } \\
\text { stomum }\end{array}$ & $\begin{array}{c}\text { Posthodiplo } \\
\text { - } \\
\text { stomum }\end{array}$ & $\begin{array}{l}\text { S.mora- } \\
\text { veci }\end{array}$ & $\begin{array}{l}\text { C.yam- } \\
\text { agurii }\end{array}$ \\
\hline B. bayad & $t$ & + & + & + & + & - & + & + \\
\hline B. docmac & \pm & + & + & + & + & - & + & $=$ \\
\hline Sschall & $=$ & - & + & + & - & - & $t$ & E \\
\hline S. serratus & - & - & $t$ & + & - & $\overline{-}$ & $t$ & - \\
\hline Barbus bynni & $=$ & - & - & $t$ & + & + & - & $=$ \\
\hline $\begin{array}{l}\text { Mormyrus } \\
\text { caschive }\end{array}$ & - & $\overline{-}$ & 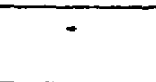 & + & - & - & - & + \\
\hline $\begin{array}{l}\text { Labeo } \\
\text { riloricus }\end{array}$ & - & - & - & + & + & + & - & - \\
\hline Lales niloticus & - & - & $\mp$ & + & + & - & $f$ & + \\
\hline
\end{tabular}

Table (11): Host-specificity of the examined parasitss 


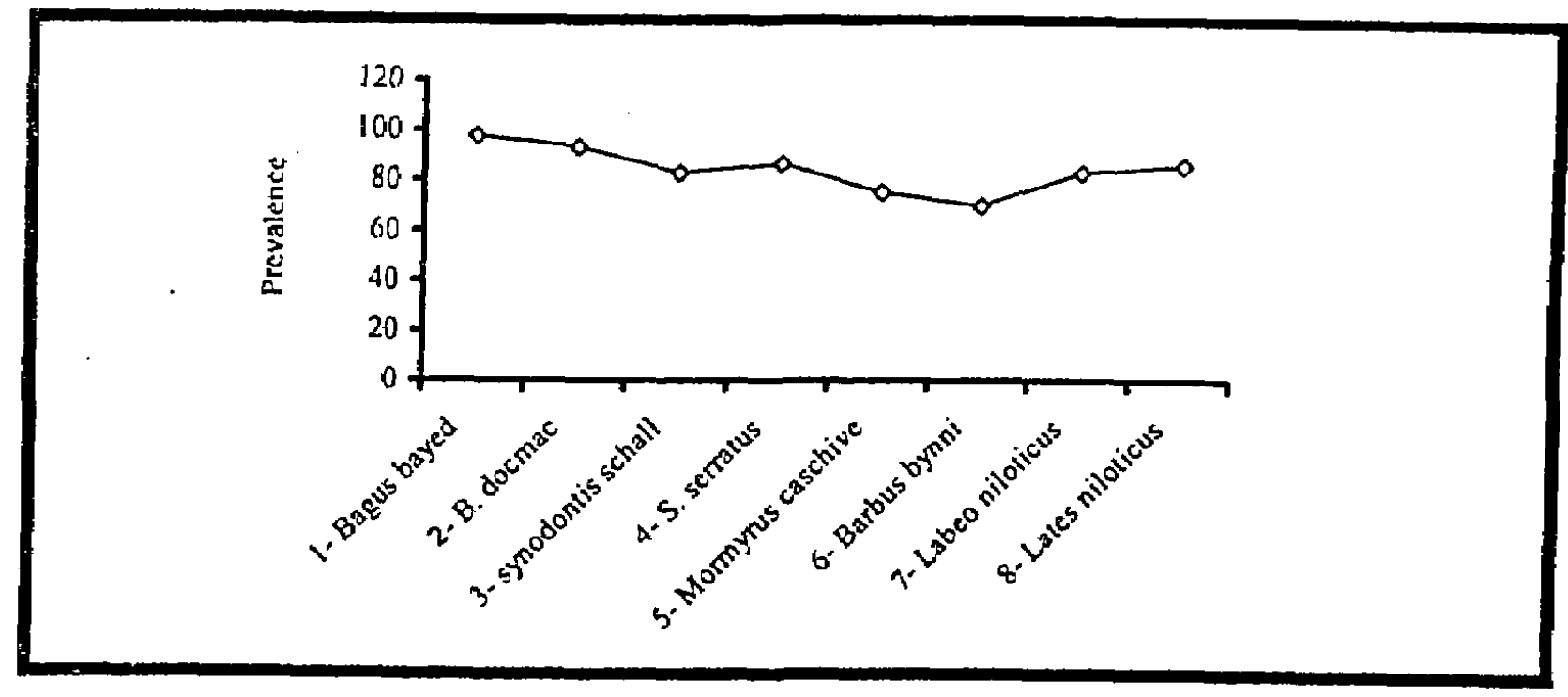

Fig. (1): General prevalence of infection in the examined hosts.

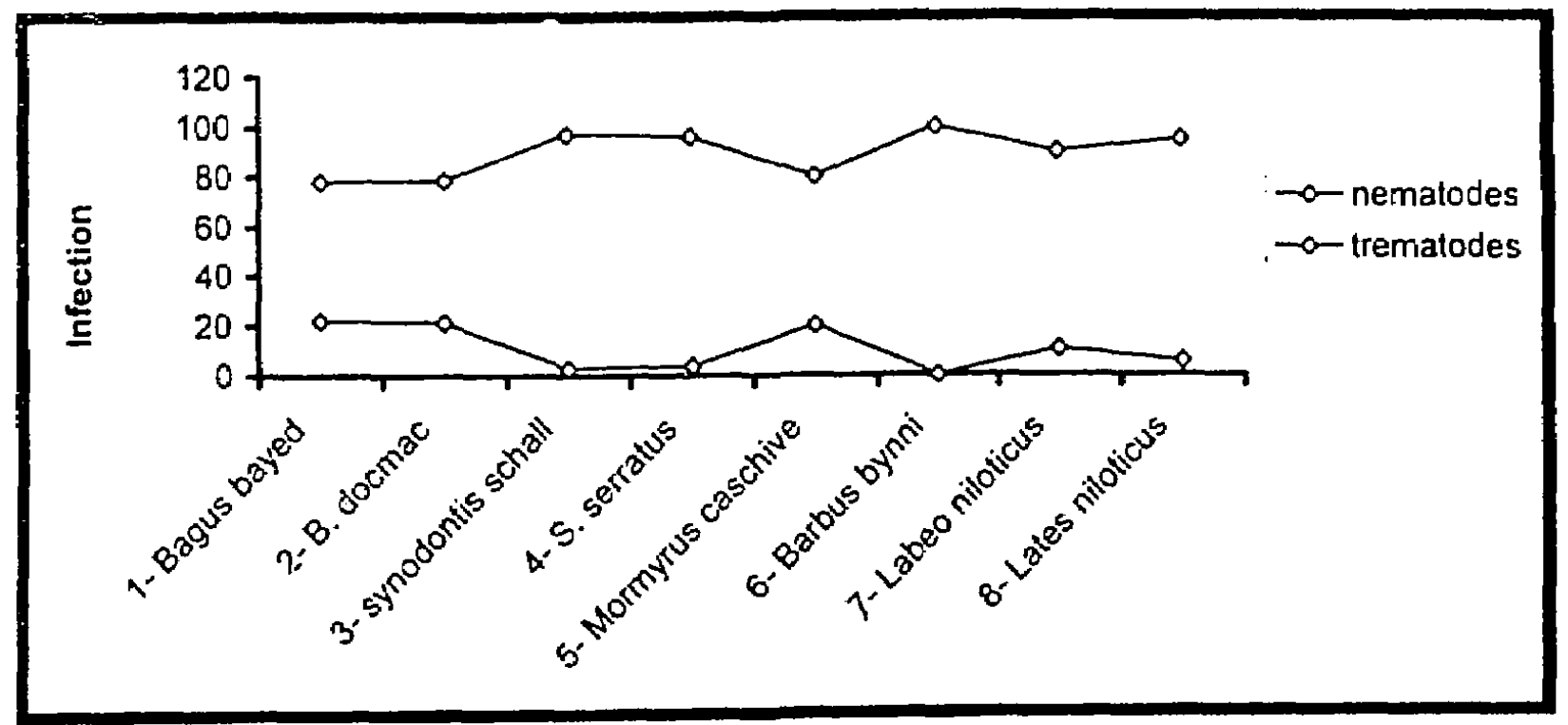

Fig. (2): the community structure of the helminth parasites infected the examined fresh waterfishes. 


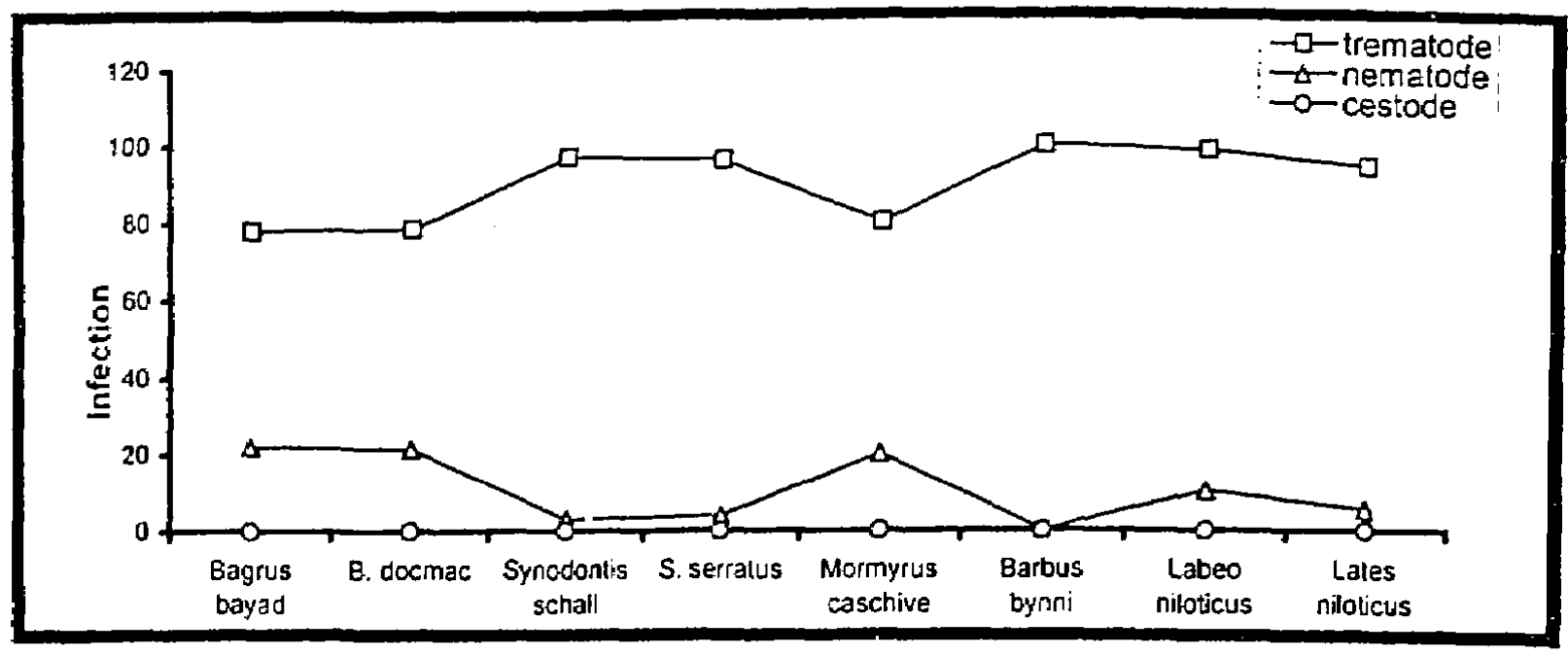

Fig. (3a): Single infection in the studied freshwater fishes:

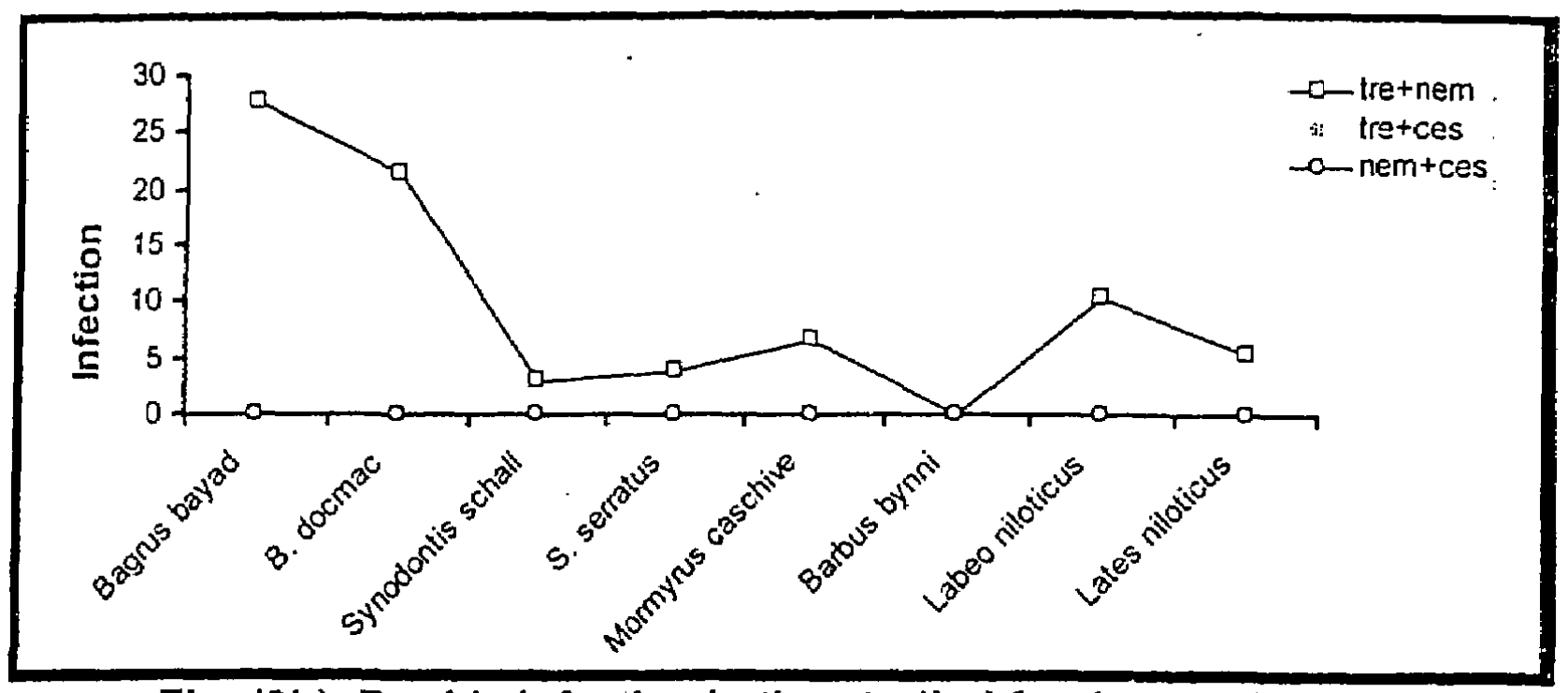

Fig. (3b): Double infection in the studied freshwater fishes. 


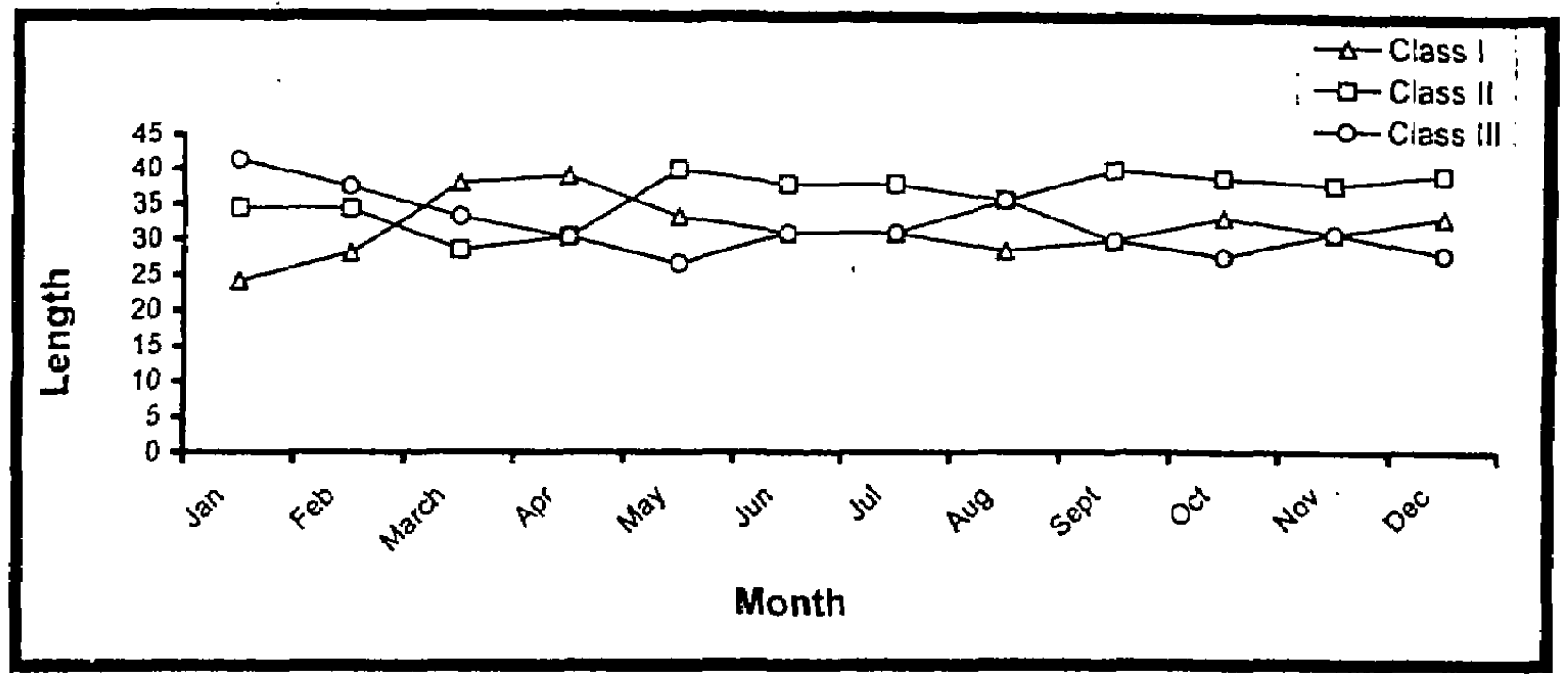

Fig. (4): Relation between the host length and prevalence of infection.

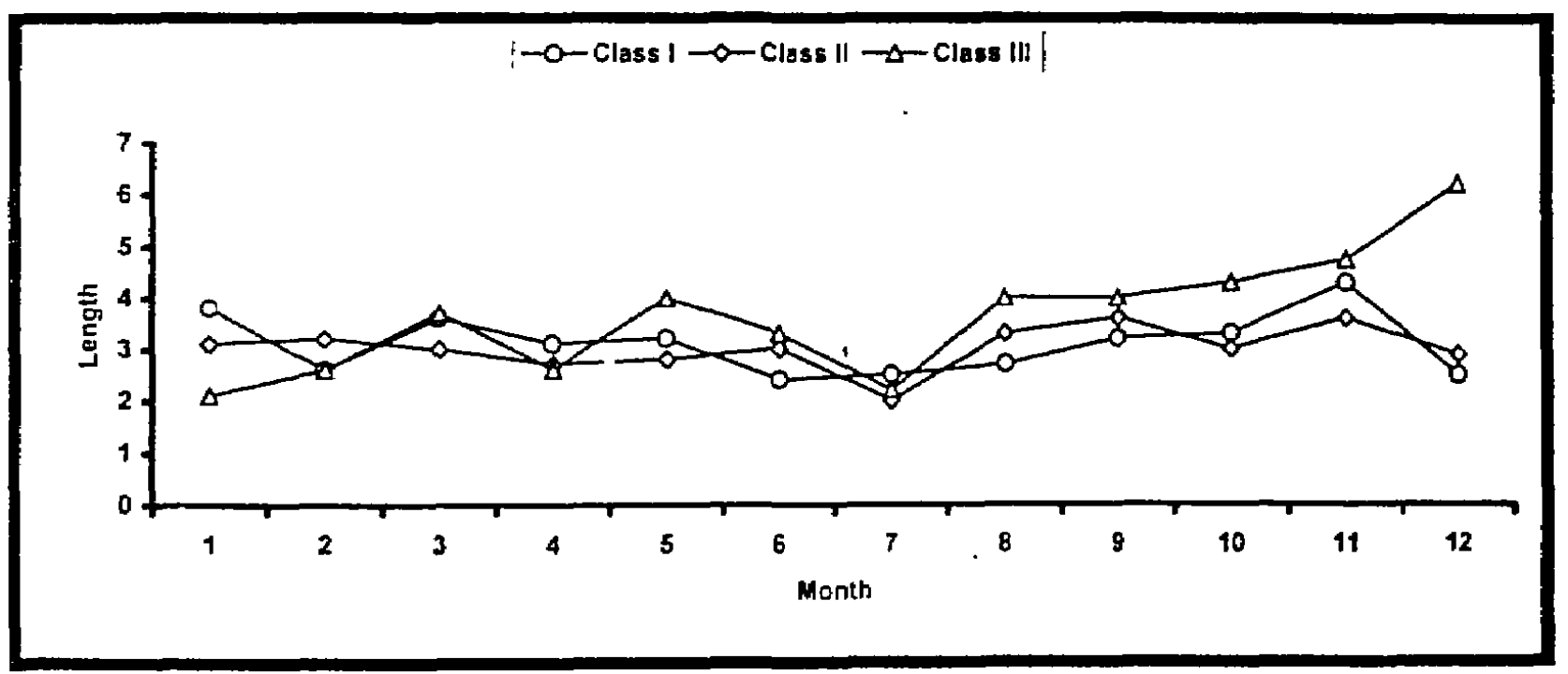

Fig. (5): Relation between the host length and intensity of infection 


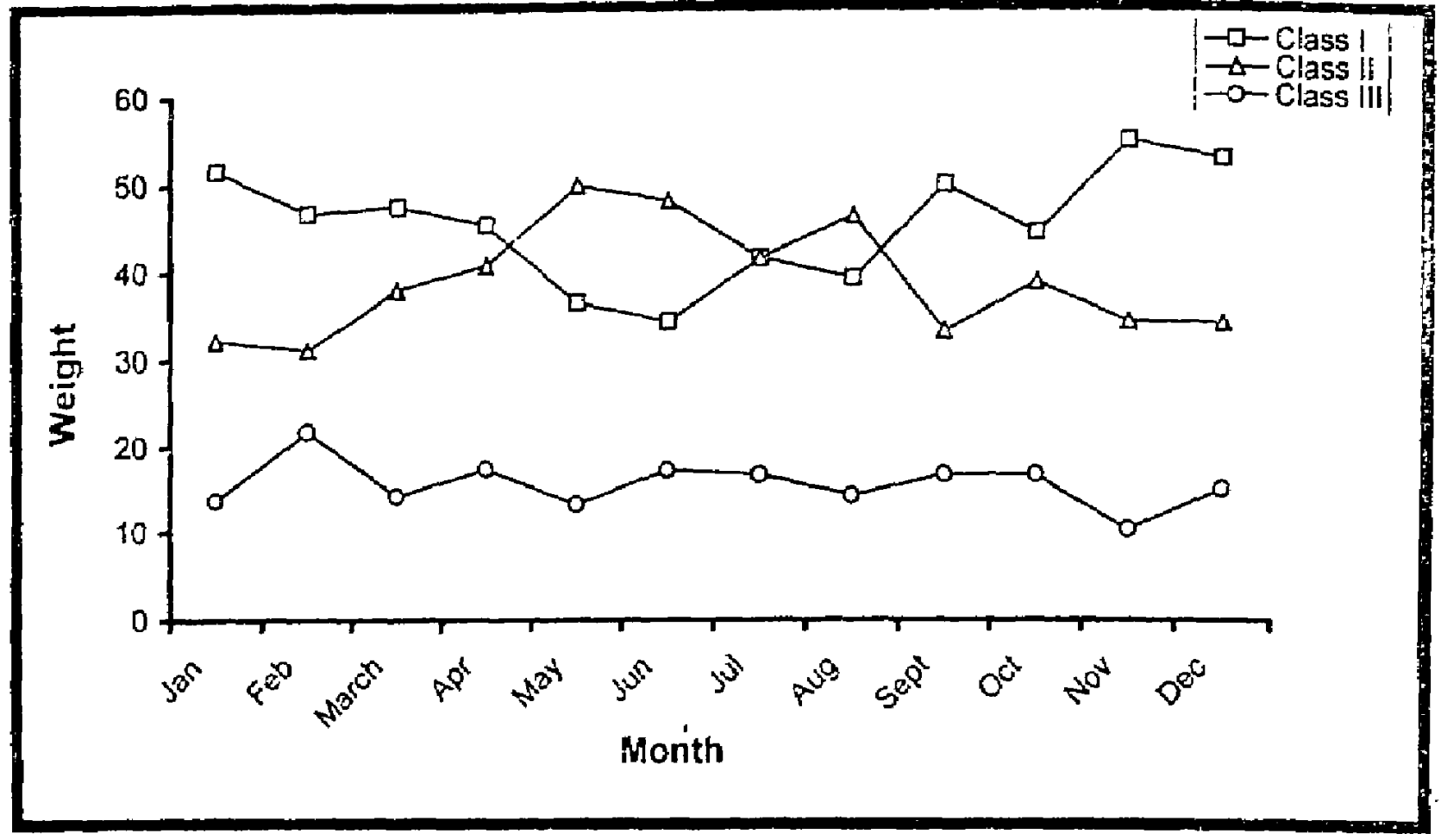

Fig. (6): Relation between the host weight and prevalence

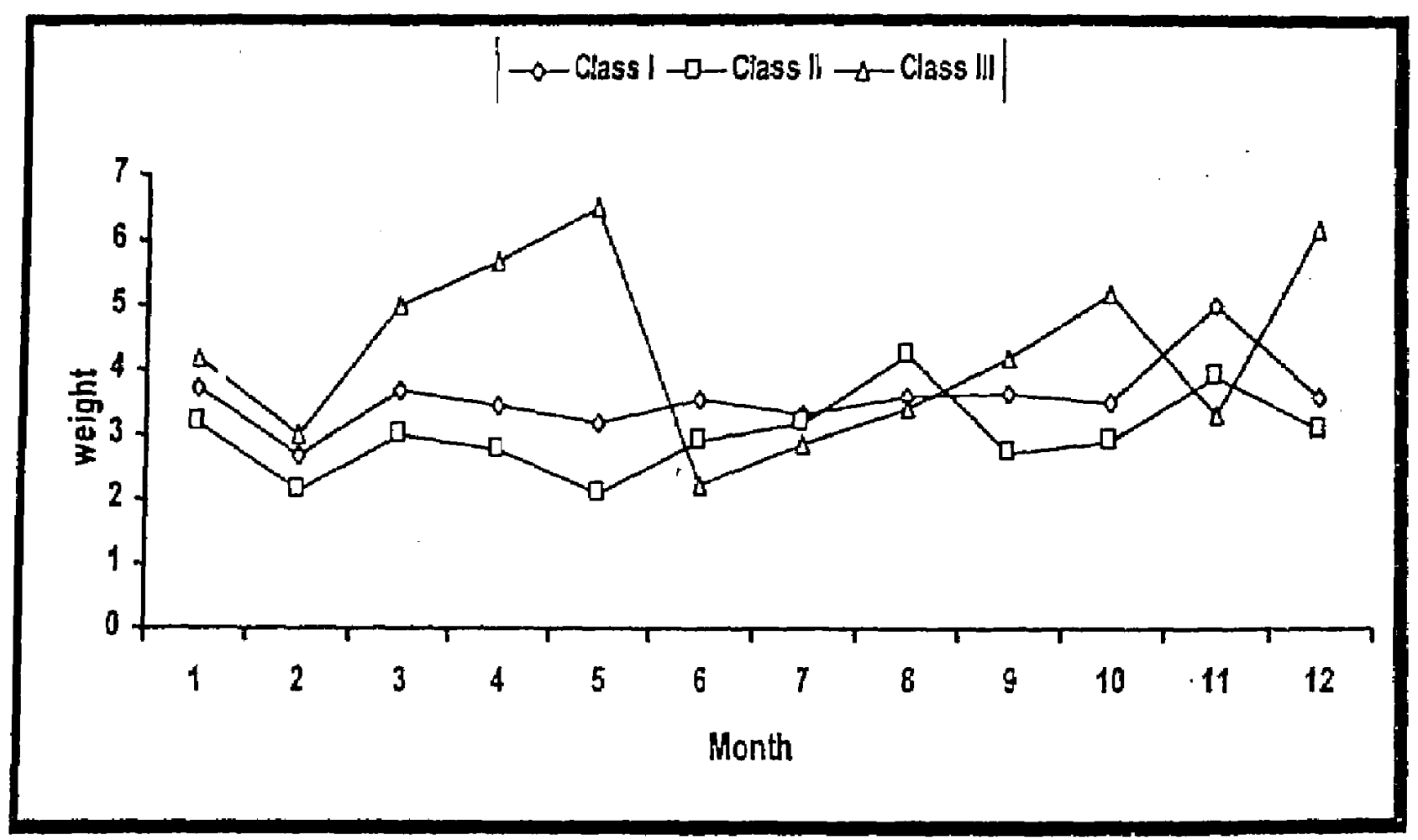

Fig. (7): Relation between the host weight and the intensity of infection. 


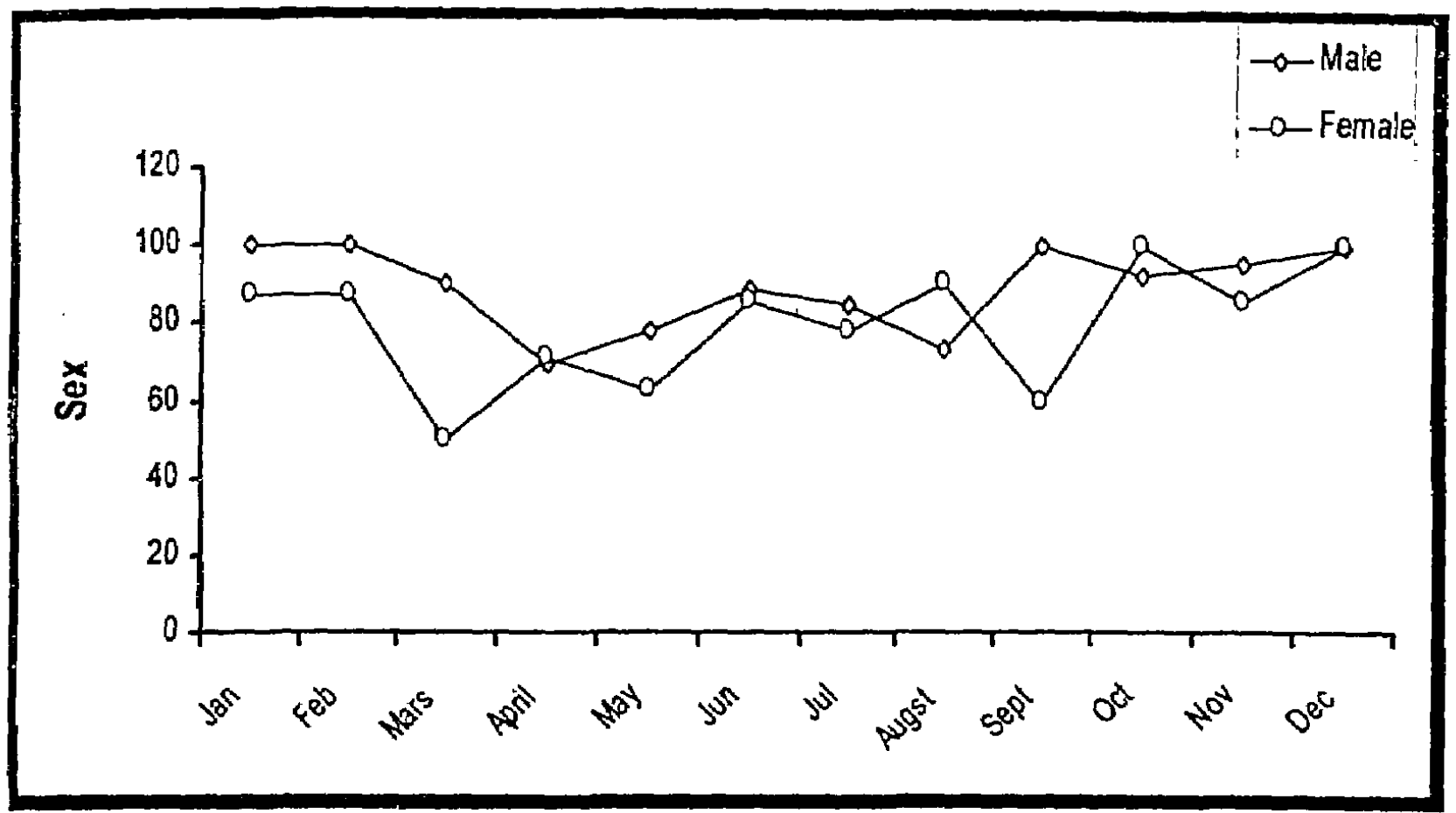

Fig (8): Relation between the host sex and prevalence of infection.

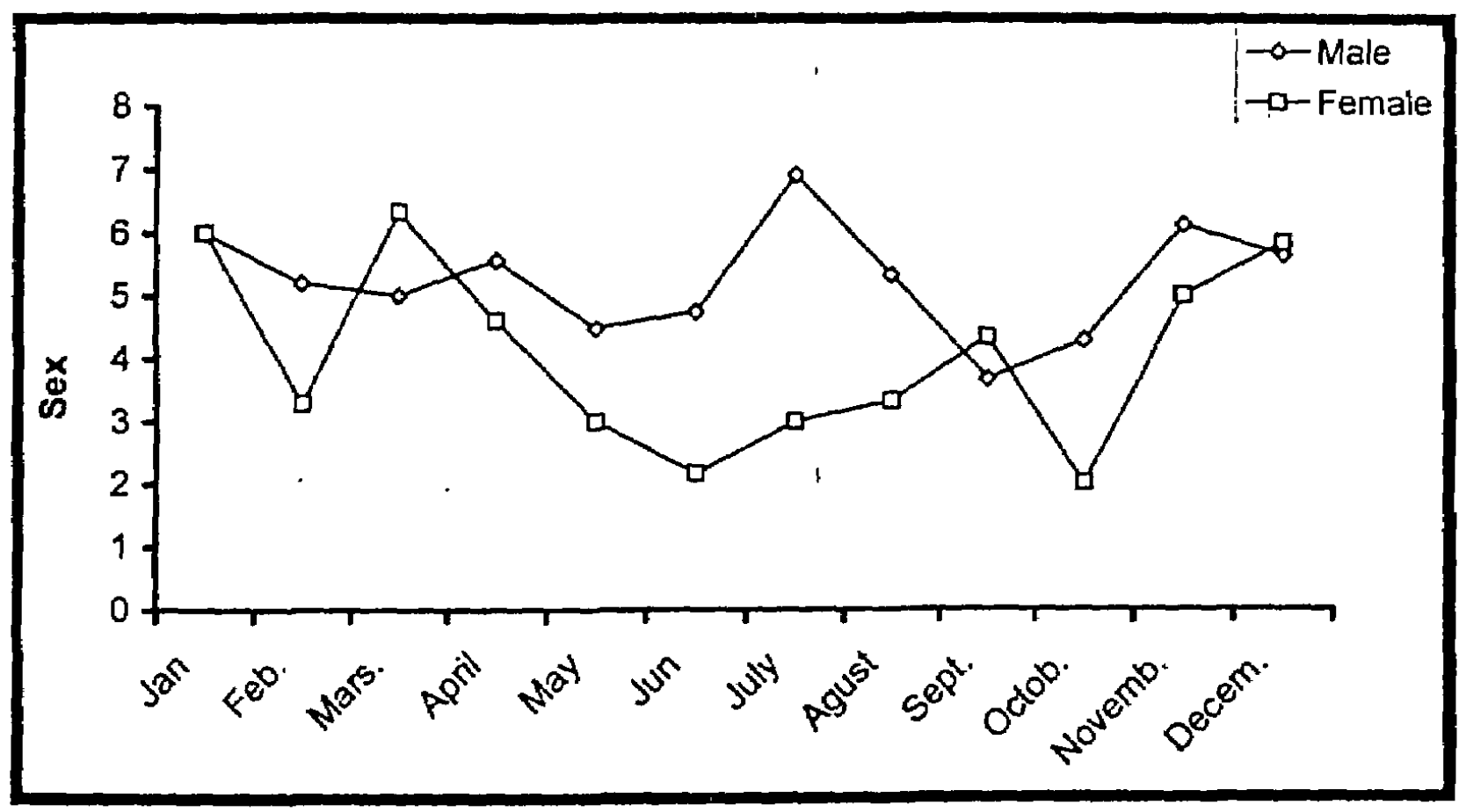

Fig. (9): Relation between the host sex and the intensitv of infection 